By ROBERT W. ORR

\title{
Television and the Library at Iowa State
}

Robert $W$. Orr is director, Iowa State College Library, Ames, Iowa.

$\mathrm{C}^{\mathrm{P}}$ To Now the question of how college libraries can most effectively contribute to the activities of educational television stations has largely remained unanswered because of an almost total lack of such TV facilities. The Iowa State College, it might be noted, was the only institution of higher education to be granted a license for a television station prior to the freeze which was imposed by the U. S. Federal Communications Commission on September 30, $1948 .^{1}$ With the lifting of this three and one-half year old ban, however, the extent and nature of participation by libraries in television activities could well become matters of nation wide importance. ${ }^{2}$ It may be of interest at this time, therefore, to review briefly the limited activities of the Iowa State College Library in connection with the programs of the collegeowned television station, WOI-TV.

As a public, tax-supported institution, the Iowa State College in the operation of WOI-TV proposes as a major objective to

1 The nation's first educational television station, WOITV, owned by the Iowa State College, began operation on February $2 \mathrm{r}, \mathrm{1950}$, on Channel 4. At first the station was equipped only for film presentations, being without television cameras and other essential studio facilities television cameras and other essential studio facilities
needed for the production of TV shows. Subsequently, needed for the production of TV shows. Subsequently,
the station obtained such equipment, and the first locally produced live telecast was made on March 2, 1951. On September 30 , 1951, WOI-TV was connected to the transcontinental live television relay system which was extended from Chicago to this area and later to the West Coast. This connection enabled the station to telecast selected shows supplied by the television networks.

2 According to a press release issued on April 14, 1952 , by Ralph Steetle, executive secretary of the Joint Committee on Educational Television, 838 colleges, uni. versities, school systems, and public service agencies, including $\mathrm{I} 6$ libraries, filed formal statements in response including I6 libraries, filed formal statements in response to the FCC's proposal for reservation of
ments for noncommercial educational use. develop, produce, and broadcast instructional and informational television programs with cultural and entertainment values. Obviously, the library has rich resources among its collections of books, periodicals, picture files, and other materials which can and should be utilized whenever possible in the attainment by WOI-TV of the objective stated above. Moreover, in keeping with their sustained record of morê than 25 years of direct participation in the planning and voicing of radio programs related to books and periodicals, the library staff members are ready to give all possible assistance to WOI-TV. At present, however, it is clear that the demands in personnel and staff time for television activities on any substantial scale by the library are such that special personnel for this specific purpose would be necessary.

The television activities of the library to date fall into two categories. The first of these comprises the assistance which is routinely supplied by the Circulation and Reference Departments. The second category of activities includes assistance in the planning of and direct participation in television programs. The library's activities of this nature have been confined to participation in three shows which belong in two series of programs known as (I) "Books on Trial" and (2) "This Is Iowa State."

Included in the first category are such commonplace services as ( $\mathrm{I}$ ) lending books as "props" for a TV "office" used by a member of the Department of History and Government in a series of lectures on world affairs, (2) supplying pictures of the 
Korean war and other national and international situations as well as of world figures such as Rommel, Nehru, Peron, Churchill, and Farouk, (3) furnishing trade information about new books, and (4) supplying miscellaneous information and assistance needed by members of the WOI-TV staff. Such services as these for television purposes, of course, are not considered to be unusual in any sense inasmuch as they are available to anyone on request.

The first of the two series of TV programs mentioned above is similar to the well-known TV book program originating in New York called "Author Meets the Critics." The WOI-TV adaptation of this show, "Books on Trial," was first produced in May, 1951. It employs no scripts and is unrehearsed and informal. It is presently broadcast from 8:30 to 9 o'clock Tuesday evenings. The personnel of the shows as seen by the TV audience comprises a member of the Department of English and Speech who serves as moderator, two guest participants, and the announcer. The two participants are chosen by the producerdirector, who is a member of the WOI-TV staff, and by the moderator. They are selected on the basis of their interest in the book and on their training and background in relation to the subject matter. The participants who have appeared to date have been men and women drawn from many walks of life, including faculty members, newspaper columnists, visiting authors, and public officials.

There is no advance discussion by the two guest participants who appear each week prior to the actual telecast except for a brief meeting to enable the moderator to give background information and instruction. It has been customary for the participants to take at least slightly opposing points of view. Actually, there is usually a large area of common agreement, with the result that the pro and con aspects of the discussion, which are never emphasized, may vary in intensity and duration from week to week. The format of the show is a relatively simple but effective one, as is indicated by the following typical example:

\section{Books on Trial}

I. Brief audio-visual feature to introduce the book.

2. Introduction of the guest participants by the moderator.

3. One-minute opening statement by each participant in which he states his position regarding the book.

4. Five-minute summary of the book by the moderator.

5. Twelve-minute discussion by the participants and the moderator.

6. One-minute concluding statement (sometimes omitted) by each of the participants.

7. Announcement by the moderator of the book chosen for the following week and the names of the persons scheduled to take part in the discussion.

Perhaps the first of these items is the only one which may not be self-explanatory. Several examples will serve as illustrations of the types of audio-visual introductions which have been used. When Toscanini's biography The Maestro was discussed, the introductory feature was a short sequence of sound film showing Toscanini conducting a symphony orchestra. A brief dramatic sketch produced by the WOI-TV staff was used to introduce Algren's The Man with the Golden Arm. When James Joyce's Ulysses was discussed, the introductory feature comprised the reading of a short passage from the book.

A member of the library staff has appeared twice on "Books on Trial." The first time was at the Iowa State Fair in August, 195I, where WOI-TV facilities had been installed temporarily. Appearing with him on this occasion was the librarian of the Des Moines Public Library. The book discussed on that date was Heyerdahl's 
Kon-Tiki. The staff member's second appearance was in December 195I, when he and a member of the Department of Technical Journalism discussed the book Horace Greeley, Voice of the People, by William H. Hale.

"Books on Trial" should be of interest as a possibility for a library book program on television. Although at Iowa State it was originated and is produced and directed by a member of the WOI staff, "Books on Trial" is a show which could be handled by a college or university library having qualified personnel and an appropriate TV outlet. It is noteworthy that this show is as popular with men as with women. Surveys have shown, for example, that book and magazine programs broadcast over WOI-AM during daytime hours are heard mostly by housewives. Fortunately, "Books on Trial" is telecast at a time when men as well as women have the opportunity to watch the show.

The series of programs known as "This Is Iowa State" is an experimental one dealing largely with informational shows of a public relations nature. It is telecast weekly by WOI-TV at 9 to 9:15 Tuesday evenings. Produced and directed by a member of the Department of English and Speech, who bears the title coordinator of radio and television education, this TV show features the activities of various departments of the college. Moreover, the show furnishes an opportunity for those taking part in it to experiment in seeking television applications for a wide variety of program situations. It is relatively simple, for instance, to plan a TV show featuring the work of the Department of Agronomy because soil conditions, characteristic of plant growth, and the like, can be effectively presented by such visual aids as charts, films, and slides. It is not so easy, however, to utilize visual materials in the production of a TV show featuring the work of the supervisor of employment.

The program on January 15, 1952, which featured the library, had as its objective the presentation to the television audience within the short space of 13 minutes a brief picture of the place of the library on the campus and illustrations of a number of the public services available to faculty members and students. Two months prior to the broadcast date, the producer-director, two members of the Information Service, and a member of the library staff spent several hours in an exploratory discussion. This meeting was followed by others at which additional persons sat in on the discussions. It was first necessary to decide upon the subject matter and then on the most effective means of presenting it on television. It would have been quite simple to plan an interview type of program, such as is commonly broadcast over AM and FM outlets. To have agreed upon such a solution, however, would have been to defeat one of the major objectives of the show; namely, the seeking of TV applications to various program situations.

As finally developed, the show employed in combination ( $\mathrm{I}$ ) film sequences made especially for the show by the Visual Aids Production Department, (2) a script prepared by a member of the Information Service, (3) musical scores selected by a member of the Music Department, (4) art drawings made by a member of the WOI-TV production staff, and (5) a member of the library staff who appeared as narrator and speaker. During the televising of the art drawings and film sequences, the library staff member presented commentary, receiving instructions during these times by earphones from the producer-director in the control booth. At other times the library staff member was in view of the television cameras as he talked directly to the television audience. Unlike "Books on Trial," the show "This Is Iowa State" employs 
carefully prepared and painstakingly rehearsed scripts.

It was decided that the public services to be featured on the library show should be those provided at the circulation and information desks and in the reserve and periodical rooms inasmuch as it is to these points in the library that readers most frequently go. To illustrate these areas of the library and to show examples of the activities which take place there, staff members of the Visual Aids Production Department came to the library and filmed several short sequences. An additional sequence was filmed in the stack area for use in connection with that part of the show which was intended to stress the variety of ianguages and subjectmatter materials represented by the book collections.

The art work used on the show comprised a simplified graphic version of the idea that libraries demonstrate one characteristic which differentiates man from animals. Animals learn directly from their kind and from experience. On the other hand, man learns in the same ways and, in addition, he has at his disposal the recorded wisdom and knowledge of previous centuries in the form of books, periodicals, and other materials held by lïrraries. It is largely because of the records in libraries that man today is able to build upon the progress which was

This is Iowa State

Tuesday, January i5, 1952

WOI-TV presents THIS IS IOWA STATE, another in the series of programs designed to take you behind the scenes of the many activities at Iowa State College. Today we visit the Iowa State College Library.

And here is $\mathrm{Mr}$. of the library. the director

Before we take up the matter of the library and what it does, I'd like to review a little history for the moment. First, let's take a look at the history of an animal.

Now, let's take a look at the history of a man-

It's apparent that animals multiplyand so does man! But man is different from an animal in that he also changes! He develops! Why: Because he has the capacity to learn from the experience of his predecessors-

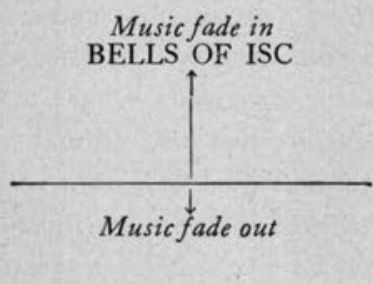

Cards

WOI TV PRESENTS

\#3

THE COLLEGE LIBRARY

$\mathrm{Mr}$.

Super-Mr.

Super-out

\begin{tabular}{|c|c|}
\hline $\begin{array}{l}\text { Music fade in } \\
\text { BARTOK-QUARTET } \\
\text { IN A MINOR (OPUS 7) } \\
\text { Beginning of side } 6\end{array}$ & $\begin{array}{l}\text { Cards } \\
\text { ANIMAL ONE } \\
\text { ANIMAL TWO } \\
\text { ANIMAL THREE } \\
\text { ANIMAL FOUR }\end{array}$ \\
\hline (Music dissolve) & (Slow dissolve) \\
\hline $\begin{array}{l}\text { MONTEMEZZI- } \\
\text { LOVE OF } 3 \text { ORANGES } \\
\text { Beginning }\end{array}$ & $\begin{array}{l}\text { MAN ONE } \\
\text { MAN TWO } \\
\text { MAN THREE } \\
\text { MAN FOUR }\end{array}$ \\
\hline (Music dissolve) & $\begin{array}{l}\text { (Slow dissolve }) \\
\text { ACFT ONE }\end{array}$ \\
\hline $\begin{array}{l}\text { AUBER- } \\
\text { MASANIELLO OVERTURE } \\
\underset{\text { Beginning }}{\uparrow}\end{array}$ & $\begin{array}{l}\text { ACFT TWO } \\
\text { ACFT THREE } \\
\text { ACFT FOUR }\end{array}$ \\
\hline
\end{tabular}

OCTOBER, 1952 
achieved by his ancestors in past centuries. It was this idea that was presented by posters and commentary at the start of the show, as illustrated by the excerpt from the script shown on the preceding page.

As college and university libraries begin to engage in television activities, it is natural to expect that various types of programs will be developed and that those referred to in this article will be only two among many. Insofar as the author is aware, very little investigation has been conducted in connection with seeking to determine what kinds of book and magazine programs are best suited for television, whether for college and university libraries or for other agencies. It is very important that extensive investigation in this field be undertaken.

As originally set forth in a statement dated March 15, 1951, the Iowa State College Library has plans for a television project designed to develop and produce experimental book and magazine programs in the belief that such programs are feasible and that they have great potentialities. It is further proposed that the project include an evaluation of the programs after a suit- able period and that a report of the project be prepared and distributed. One feature of this project as pianned provides for the appointment of a specialist who would work jointly with the Library and WOI-TV. A part of this specialist's time would be devoted to the planning and production of book and magazine programs over the AM and FM outlets as well as over television.

The two series of television programs which have been described in this article constitute appropriate examples which college and university libraries could produce and direct when the institutions of which they are a part begin operating television stations. In many instances libraries will probably wish to accept responsibility only for occasional programs rather than for every show in one or more series, especially if the series is a weekly one. The degree of success of "Books on Trial" over WOI-TV indicates that this type of book program may have attractive possibilities for other educational television stations. The same can be said of "This Is Iowa State," although its primary purposes are public relations and experimentation in television techniques.

\section{Information Wanted by ALA's International Relations Board}

If you have employed foreign librarians or foreign library school students on a full-time or a part-time basis within the last few years, the International Relations Board of the ALA would be grateful for the following information. Who were they; from what countries did they come; how did they happen to come to your library; who provided cost of transportation; how did you pay them-private funds, special arrangement with town, city or state authorities, etc.; what were the major difficulties and how did you overcome them; what were your experiences with the librarians from abroad; would you employ them again? This information will be confidential but will help the IRB in answering questions about exchange of librarians and the employment of foreign librarians. Please send your data to Margaret C. Scoggin, superintendent of Work with Schools, The New York Public Library, 127 East 58th Street, New York City 22. 